Miracle word. N. 12, P. 14-22.

4. Donchenko, T. 2003. Vzayemozv'yazok perekaziv i tvoriv u procesi formuvannya movlennyevoyi diyal nosti shkolyariv [The relationship of stories and works in the process of forming the speech activity of students]. Ukrainian language and literature at school. $\mathrm{N}$. 1, P. 8-11.

5. Zaxarova, O. 2007. Movna kul tura yak meta urokiv ukrayins`koyi movy` [Language culture as the purpose of Ukrainian language lessons]. Ukrainian language and literature. May, P. $13-15$.

6. Karaman, S. 2004. Vy`dy` robit z rozvy`tku zv'yaznogo movlennya [Types of work on the development of coherent speech]. Ukrainian literature in secondary schools. N. 4, P. 18-20.

7. Murzha, L. 2007. Rozvy`tok zv'yaznogo movlennya: sy`stema, problemy`, shlyaxy` vdoskonalennya, vy`dy` kontrolyu [Development of coherent speech: system, problems, ways of improvement, types of control]. Ukrainian language and literature. N. 2, P. 3-5.

8. Podlevs`ka, N. 2007. Formuvannya vmin` kul tury` spilkuvannya u vy`dax movlennyevoyi diyal'nosti [Formation of communication skills in the types of speech activity]. Ukrainian language and literature at school. N. 2, P. 2-5.

9. Skurativs`ky`j, L. 2004. Vy`vchennya movnoyi temy`yak zasib movlennyevogo rozvy`tku uchniv [Studying the language topic as a means of speech development of students]. Ukrainian language and literature at school. N. 7-8, P. 5-10.

10. Shelexova, G. 2003. Formuvannya komunikaty`vny`x umin`na urokax ukrayins`koyi movy` v 6 klasi [Formation of communicative skills in Ukrainian language lessons in 6th grade]. Ukrainian language and literature at school. N. 1, P. 4-7.

УДК 37.091.39:81'243]:37.011.3-057.87(045)=111

DOI:10.31339/2617-0833-2020-1(28)-140-144

\title{
LANGUAGE LEARNING STRATEGIES USED BY SUCCESSFUL AND UNSUCCESSFUL LANGUAGE LEARNERS
}

Siladi Vasyl

\section{СТРАТЕГІЇ НАВЧАННЯ МОВИ, ВИКОРИСТАНІ УСПІШНИМИ ТА МАЛОУСПІШНИМИ ПІЗНАВАЧАМИ МОВИ}

Сіладі В.

The subject matter of this paper is strategies used by successful and unsuccessful language learners in the process of learning English as a foreign language. The importance of such a research lies in that language learning which strategies might be the key to the success of each student in the learning process.

Under the term 'language learning strategies' different techniques and methods are meant, i.e. guessing, learning both inductively and deductively, classifying new words, thinking in the target language, reading English publications etc. Researchers have mostly dealt with second language learning, although their results and conclusions can be applied to the process of learning a foreign language.

The early steps to the investigation of foreign language learners were the studies of Rubin [8] and Stern [9]. The two researchers collected a number of strategies, which could discriminate between successful and unsuccessful learners. Researchers intended to construct a list of strategies used by the so-called 'successful or unsuccessful' learners. They considered that if a person uses these strategies, he/she can be successful in learning a foreign language, i.e. grammar, phonology, lexicon, historical events and cultural aspects. However, Abraham and Vann [1] in their research proved that both good and poor language learners use nearly the same strategies as to their amount 
and kinds, but the problem is that unsuccessful learners cannot use these strategies in a proper way. Poor learners do not succeed in choosing the suitable learning strategies in a certain situation.

Surveys by Horwitz [6] and Wenden [10] attempt to find out why students cannot choose the proper strategies, and which are those factors that influence their choice. The aim of this paper is to identify and demonstrate which foreign language learning strategies are used by the first, second and third year English major students of the Transcarpathian Hungarian Institute named after Ferenc Rakoczi II.

Key words: learning strategy, successful student, unsuccessful student, technique, inhibited, suitable, inductive, deductive, etc.

Стратегії для навчання, обрані в прочесі вивчання мови, відіграють важливу роль в успішному мови. Використання таких засвоєнні технік і методів, як здогадка, індуктивне та дедуктивне навчання, групування нових слів, читання на іноземній мови - все це відноситься до категорії стратегій вивчання мови.

Ключові слова: стратегія навчання, успішний студент, невдалий учень, техніка, загальмована, підхідна, індуктивна, дедуктивна тощо.

In language pedagogy there is a great interest in the way the learners find solution to learning problems. Early research dealt only with the classical linguistic categories, i.e. grammar, phonology and semantics. Some later pieces of work were related to the background of learners' reaction to a new language and to the way they act in problematic situations, for example test-taking. These studies lay stress on communication problems and the difficulties appearing while a learner tries to perform a task in his/her new language. Strategies, which have been studied and collected during the investigation, were considered to be useful in the process of learning, and being the basis for instruction.

McDonough [5].

The early steps to the investigation of strategies of second language learners was the highly progressive work of Rubin [8] and Stern [9]. They both described strategies, which could discriminate between good and poor learners.

Rubin's [8] work, titled 'What the 'Good Language Learners' Can Teach Us' is considered to be the basis for the further investigations on the given topic. Rubin intended to find the key to the success of language learners through the strategies they use. Good language learning is said to depend on three variables: aptitude, motivation, and opportunity, as Rubin [8] comments in her article. Aptitude is considered to be the subjects, which might not be changed easily. This point is very frequently a matter of discussion in literature. Some authors point out that language aptitude is "a relatively invariant characteristic of the individual, not subject to easy modification by learning Carroll, [2] cited in Rubin, [8]

By strategies, Rubin means, "different techniques the learner may use to acquire knowledge" Rubin, [8]. She mentions seven strategies used by the good language learner (GLL). The first strategy is guessing. A GLL tries to find out the meaning of even unknown words with the help of context, their cultural background, or by trying to think in the way the writer of that text was thinking while writing it. Guessing is also based on grammar and lexicon. The second strategy in Rubin's list of strategies is communication and learning with the help of communication. The learners, who are ready to communicate despite their mistakes, acquire the language more efficiently. The aim is to get their message across, it does not matter how.

The third statement about the GLL is that the good language learners are often not inhibited, i.e. they will ask questions, for example, the answers to which they may know, in order to learn new words or grammatical structures.

The fourth strategy is attending to form, i.e. inductive learning of lexical and grammatical patterns. The next strategy is practicing. The GLL often initiates discussion with people, who know the language the GLL is learning. Such a learner is a good risk-taker. The sixth strategy is monitoring. 
The GGL monitors his own speech and the speech of other speakers. The last strategy, mentioned by Rubin [8] is attending to meaning. The learner who uses this strategy knows that it is useless to pay attention to every word in the text or sentence. He goes under the surface of words and sentences. He chooses some words, which are of most help to him, and does not pay attention to every unfamiliar word. Learners improve their knowledge through training and they dismiss the unfamiliar information. All these strategies are connected to each other, and help the learner, who uses them, to see the whole picture, with background, association and under surface information. Carroll [2], in Rubin [8], suggests "the most numerous kinds of association that are made to an item, the better are learning and retention".

Strategies mentioned above will depend on some circumstances, such as "the task, the learning stage, the age of the learner, the context, individual styles, cultural differences", as Rubin [8] puts it. In an article, Stern [9] gives a list of more learner strategies. He points out ten strategies, as being "features that mark out good language learning". The list is the following:

1. A personal learning style or positive learning strategies.

2. An active approach to the task.

3. A tolerant and outgoing approach to the target language and empathy with its speakers.

4. Technical know-how about how to tackle the language.

5. Strategies of experimentation and planning with the object of developing of new language into an order system and revising this system progressively.

6. Constantly searching for meaning.

7. Willingness to practice.

8. Willingness to use the language in real communication.

9. Self-monitoring and critical sensitivity to language use.

10. Developing the target language more and more as a separate reference system, and learning to think in it

There are many similarities between Stern's [9] and Rubin's [8] lists of strategies. Both of them stress practice, using the language in real communication, trying to understand the context, empathy with people of another cultural background. As to monitoring, Rubin [8] mentions selfmonitoring, and monitoring the speech and performance of the others, while Stern [9] does not speak about monitoring the other speakers. Another very important difference should be pointed out: in the work of Stern [9] one can find that language learners have to think in the new language. With the help of it learners can identify themselves with the target language, the new cultural and social life.

Later on, with the developing of the science about learning strategies appeared a new term 'learner strategy' (Cohen, [3] Wenden [10] \& Rubin [8], McDonough, [5]) as opposed to the term 'learning strategies'. The researchers wanted to pinpoint that learners differ from one another, and that they may have individual learning strategies. Then, a common question came into the surface of the problem: What motivates learners, when they use their strategies? What influences the choice of their strategies? There were a few investigations, which wanted to find the answer to these questions. In the conclusion of his study Omaggio [10], and Wenden, [10] points out the strategies of GLLs, saying that a language learner has "insight into the nature of the task (of learning)". Hosenfeld ([4], in Wenden, [10]) mentioned the so-called 'mini-theories' of second language learning, i.e. each language learner has his/her own theory how to learn a language.

Wenden [10] was one of those investigators, who stressed the background of the strategies, the so-called beliefs and assumptions, which underlie the choice of that strategies by second language learners. It means that some learners think one thing to be important and the others something else. The result of Wenden's [10] investigation was that she divided the learners into three groups. The first group stressed the importance of using the language. One has to visit places where one has an opportunity to communicate with other people. The best is to live in the country where the target language is spoken, and try to think in one's target language. Thinking in the target language was also mentioned by Stern [9]. 
The second group indicated that the most important factor in the process of learning is to learn about the language. One could not learn a language without grammar, rules, teacher, and a formal course. These learners wanted to be led by people who were good at that second language, they wanted to be monitored by teachers. The second group was led by cognitive strategies, while the first one by communicative ones.

The third group said that the so-called 'personal factors' were the most important in the efficient learning process, that is the ability of the students to

learn a language and also their attitude towards the given language. Despite the differences among the three groups, there are a few similarities. All the learners take into consideration vocabulary more frequently than syntax, grammar and phonology. Wenden [10]. Autonomous learning in Wenden's [9] opinion means that learners are ready to take risk; they try to develop their language knowledge and take responsibility for their learning. In their research, Abraham and Vann [1] give a detailed list of strategies. They divided strategies into two large groups, cognitive strategies and communicative ones. Communicative strategies include past experiences, feelings, emotions, trying to express the message. When learners use these strategies, they just try to be a member of a large group that is a group of people, who speak the same language. Cognitive strategies according to Abraham and Vann [1] mean stressing on meaning and form. Based on previous researches an investigation was carried out at the Transcarpathian Hungarian Institute named after Ferenc Rakoczi II to find out which strategies were used by the students majoring in English. The research instrument was a questionnaire. A pre-questionnaire and a final questionnaire was completed and filled in by the students and the results a given in the conclusions.

Language learning strategies are important issues in pedagogy, because they can help students to be more successful in the learning process of a foreign language. All learners use some strategies, but they have to study to use them in

a proper way. This thesis gives a sort literary review to demonstrate the developing of this branch of science which studies learning strategies used by students in the process of learning.

A questionnaire was prepared to find out the strategies used by the learners of Transcarpathian Hungarian Institute named after Ferenc Rakoczi II. The questionnaire is based on a pre-questionnaire that is a pilot work, which was completed with the help of graduated students of English faculties now studying in Uzhgorod National University.

The final questionnaire was completed by year I, II, III, and IV English majors. The participants were asked to mark if they agree with the statements of the questionnaire or not. The results show that there are strategies and beliefs, which are appreciated by participants, i.e. speaking with English people, visiting English speaking countries, reading English books and newspapers. It was not a

great surprise because these aspects are quite popular and emphasized during the whole learning process. Among the strategies, which were marked useless, were guessing, while learning new material and not translating each unknown word, using imagination during learning and speaking about the strategies used by the other learners.

These are the points that need further investigation and improving.

It is important to carry out such a research in Transcarpathian Hungarian Institute because not many have concentrated on the language learning strategies before so when learners use strategies and they do use them, they do it not consciously. Teachers have to point out the importance of strategies during learning foreign languages and to teach their students how to study more effectively. The survey shows a picture of the strategy-using traditions of English major students Transcarpathian Hungarian Institute named after Ferenc Rakoczi II. The paper is believed to give detailed analysis of students' attitudes to the process of learning and to their own knowledge and achievements in some detail. It can be of great use for those teachers who agree with the fact that the more strategies a student uses the more successful he might be in learning and acquiring a foreign language. 


\section{References}

1. Abraham, R. and Vann, R. 1987. Strategies of two learners: A case study. In: A.L. Wenden and J. Rubin eds. 1987. Learner Strategies in Language Learning. New York: Prentice Hall. pp. 85-102.

2. Carroll, J. B. and Sapon, S. M. 1983. Modern Language Aptitude Test (MLAT): Manual. New York: The Psychological Corporation Harcourt Brace Jovanovich.

3. Cohen, A.D. 1998. Strategies in Learning and Using a Second Language. Essex, U.K.: Longman.

4. Hosenfeld, C. 1979. A learning-teaching view of second language instruction. Foreign Language Annals, 12, pp. 51-57.

5. McDonough, S. 1995. Strategy and skill in learning a foreign language Edward Arnold. London.

6. Naiman, N., Frцclich, M., Stern, H.H. and Horwitz, E. 1987. Surveying student beliefs about language learning. In: A. Wenden and J. Rubin. 1987. Learners strategies in language learning. New York: Prentice Hall.

7. Omaggio, A. 1986. Teaching language in context: Proficiency oriented instruction. Boston, MA: Heinle \& Heinle.

8. Rubin, J. 1975. What the good language learner can teach us. TESOL Quarterly, 1, pp. 4151.

9. Stern, H.H. 1975. What can we learn from the good language learner? The Canadian Modern Language Review, 31, pp. 304-318.

10. Wenden, A. 1987. How to be a successful language learner: Insights and prescriptions from L2 learners. In: A. Wenden and J. Rubin. 1987. Learner strategies in language learning. New York: Prentice Hall.

УДК [316.77:37.091.12:159-051]:316.7-057.4(045)

DOI:10.31339/2617-0833-2020-1(28)-144-151

\section{КОМУНІКАТИВНИЙ ПОТЕНЦІАЛ ОСОБИСТОСТІ ПСИХОЛОГА - ПЕРЕДУМОВА ФОРМУВАННЯ КОМУНІКАТИВНОЇ КУЛЬТУРИ ФАХІВЦЯ}

Соломка Е.Т., Олійник В.В., Іваць О.М., Хлопек А.Б.

\section{COMMUNICATIVE POTENTIAL OF A PSYCHOLOGIST PERSONALITY- PRECONDITION FORMATION OF COMMUNICATIVE CULTURE OF A SPECIALIST}

Solomka Edward, Oliynyk Vasyl, Ivats Oksana, Khlopek Adam

У статті поданий теоретичний аналіз комунікативної компетентності психологів в процесі професійної діяльності. Розкрито сутність понять “компетенція”, "компетентність", “комунікативна компетентність", “професійна комунікативна компетентність”. Охарактеризована комунікативна компетентність психолога як базова компетенція його професійної діяльності.

Ключові слова: компетенція, компетентність, комунікативна компетентність, професійна комунікативна компетентність, ділова комунікація, ефрективність комунікації, комунікативна культура, структура комунікативної культури, психологічна компетентність.

The article presents a theoretical analysis of the communicative competence of psychologists in the process of professional activity. The essence of the concepts "competency", "competence", "communicative competence", "professional communicative competence" is revealed. The 